\title{
Lysmata dispar sp. nov., a new shrimp from the Dampier Archipelago, Western Australia, with notes on other species of the family Hippolytidae (Crustacea: Decapoda: Caridea)
}

\author{
Ken-Ichi Hayashi \\ 13-7 Yoshimi-Ryuohcho, Shimonoseki, Yamaguchi, 759-6522 Japan. \\ email: hayadomus(ujcom.home.ne.jp
}

\begin{abstract}
A new species, Lvsmata dispar, was found from a collection of shrimps from the Dampier Archipelago. It bears an unequal second pair of pereopods, with the carpus having more than 30 subsegments, and a comparatively long stylocerite. The combination of these characters distinguishes $L$. dispar immediately from all known species. A full description of this species and a list of a further eight species of seven genera of the family Hippolytidae, with short notes on three members new to Australian waters, is presented.
\end{abstract}

\section{INTRODUCTION}

The hippolytid genus Lysmata has recently been reviewed several times and contains about 30 species from worldwide tropical to warmtemperate regions (Chace, 1997; Wicksten, 2000a, b; Burukovsky, 2000). Chace (1997) presented a list of 25 species known at that time with a key to all of them. Wicksten $(2000 \mathrm{a}, \mathrm{b})$ enlarged this genus, including four new species from the East Pacific, with a key to eight eastern Pacific species. About one-third of the known species are described from the Indo-West Pacific region (Chace, 1997). Of these, the following three have been recorded from Australian waters (Davie, 2002), L. amboinensis (De Man, 1888), L. ternatensis De Man, 1902, and L. vittata (Stimpson, 1860).

Among the samples of a survey of the Dampier Archipelago, carried out by the Western Australian Museum, three species of this genus were found. Two are the well-known species, L. multiscissa (Nobili, 1904) and L. vittata. The third is a new species, somewhat related to $L$. multiscissa, but bearing an unequal second pair of pereopods, with a carpus with more than 30 subsegments, and a comparatively long stylocerite. These characters immediately distinguish this species from all the known species.

The present paper describes this new species in detail, with figures, and briefly introduces new members of the hippolytids to Australian waters, as well as a list of other species collected from the Dampier Archipelago.

\section{MATERIALS AND METHODS}

The specimens examined are all deposited at the Western Australian Museum (WAM). The specimen size is measured as carapace length (CL), from the posterior margin of the orbit to the posterior margin of the carapace. Other abbreviations are as follows: juv.(s), juvenile(s); ovig. ovigerous; stn, station. Species with an asterisk $\left(^{*}\right)$ are new to the Australian fauna

\section{SYSTEMATICS}

\section{Lysmata disparsp. nov.}

Figures 1-3

\section{Material examined}

Holotype

WAM C 29212 (ovig. female, $4.9 \mathrm{~mm}$ ), stn DA3/ 99/48, Goodwyn I. (20\%32.000'S, $\left.116^{\circ} 32.420^{\prime} \mathrm{E}\right)$, intertidal, 31.08.1999.

\section{Paratupes}

WAM C 29553 (1 male, $4.6 \mathrm{~mm}$; ovig. female, $5.4 \mathrm{~mm}$ ), data same as holotype; WAM C 28089 (1 male, $4.1 \mathrm{~mm}$ ), stn DA3/99/65, Enderby I. (2037.10's, 116 26.72'E), dive, $13-15 \mathrm{~m}, 06.09 .1999$.

\section{Diagnosis}

Rostrum not overreaching antennular peduncle, rostral formula $2+4 / 2$. Carapace with prominent antennal spine discrete from orbital angle, and with small pterygostomial spine. Orbital angle visible in dorsolateral view as distinct, blunt process. Antennule with stylocerite reaching nearly to distolateral margin of first antennular segment, dorsal flagellum with very short, single joint of accessory branch. Antennal scale 3.2 times as long as wide, distolateral spine slightly overreaching blade. Third maxilliped with exopod reaching 


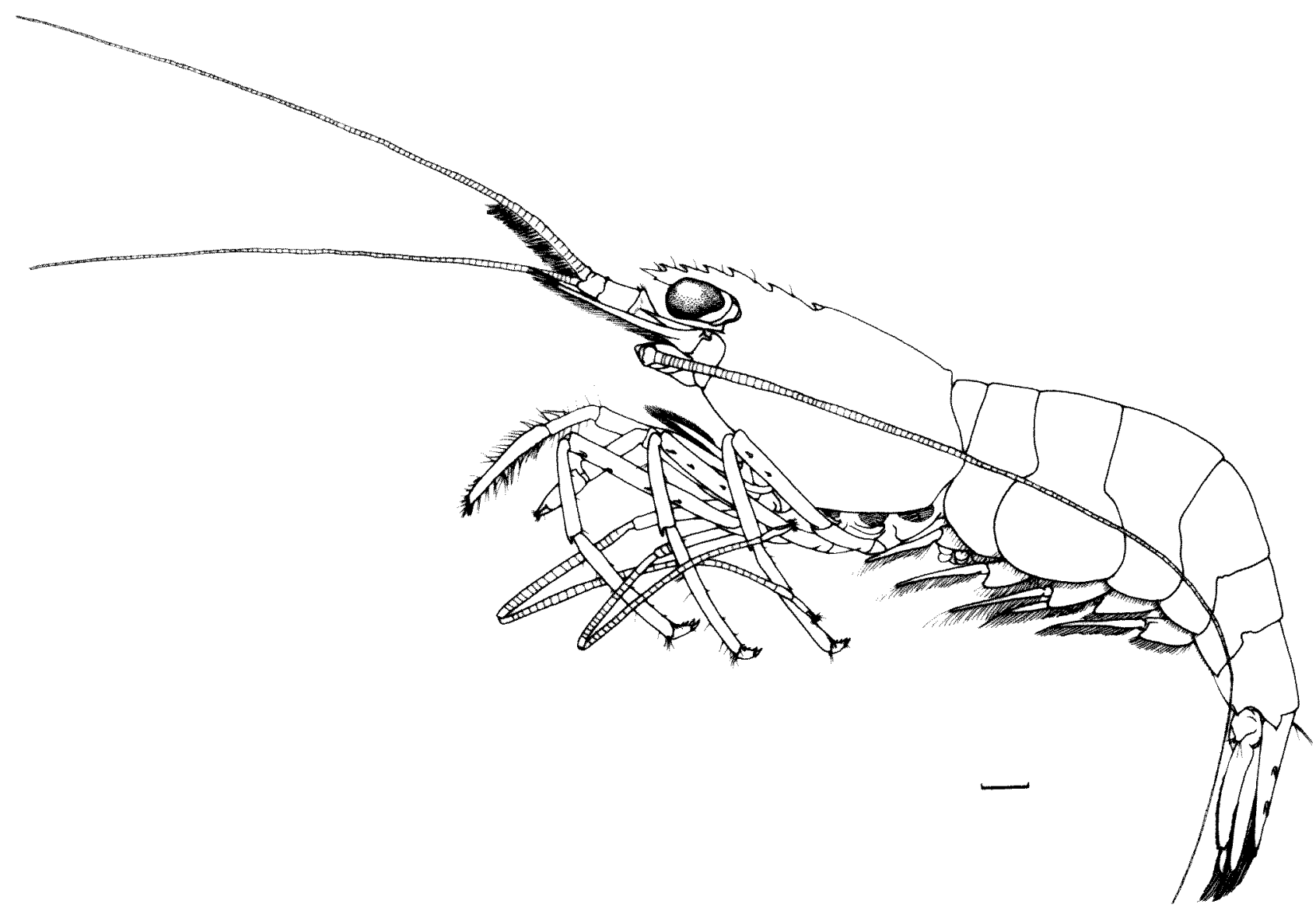

Figure 1 Lysmata dispar sp. nov.: holotype (ovig. female, CL $4.9 \mathrm{~mm}$ ), from Goodwyn Island.

beyond midlength of antepenultimate segment. First pereopod with chela 1.1 times as long as carpus. Right second pereopod longer and larger than left second pereopod; carpus composed of 30 or 32 subsegments in both sides; merus composed of 21-26 subsegments in right leg, 17-22 subsegments in left leg; ischium composed of 5 subsegments in both sides. Third pereopod with dactylus biunguiculate, with 3 spines on posterior margin. Maximum postorbital carapace length 4.1$4.6 \mathrm{~mm}$ in males, $4.9-5.4 \mathrm{~mm}$ in ovigerous females.

\section{Description}

Moderate sized shrimp with firm antennular and antennal flagella (Figure 1). Carapace smooth with strong antennal and small, acute pterygostomial spines (Figure 2b); suborbital angle rectangle curved medially; anterior margin largely concave just below antennal spine, continuing straight ventrally to pterygostomial spine (Figure $2 \mathrm{c}$ ). Rostrum nearly straight, with developed midrib, reaching end of first segment of antennular peduncle; apex sharp (Figure 2b). Dorsal margin slightly convex, with six subequal spines, posterior most tooth with faint suture at base and rather far from other fixed teeth; posterior two teeth on carapace and third tooth just above orbit; short seta present on small step at nearly mid length between succeeding two teeth from second (Figure $2 b$ ). Ventral margin sinuous, with two or three teeth on distal convex part, tuft of hairs on basal concave part (Figure 2b).

Abdomen smooth, third and fourth somites subequal, longest, and first and fifth somites subequal, shortest; sixth somite 1.8-1.9 times as long as fifth somite and 1.1 times as long as deep at base (Figure 2d). Pleura of first to third somites rounded; small spine occasionally present on that of fourth somite and always distinct sharp spine on fifth somite (Figure 2d, e). Telson tapered, and flattened dorsally, with two pairs of dorsolateral spines, proximal pair situated at proximal twofifths, distal pair at mid length between proximal pair and distal margin of telson (Figure 2f). Distal margin convex with small median point; two pairs of spines, outer short and inner long, and one pair of long plumose setae present (Figure $2 \mathrm{~g}$ ).

Eye well developed, cornea semispherical, placed obliquely on short stalk; ocellus absent (Figure 2a, h). Antennular peduncle long, stout, first segment longer than second and third segments combined, with two-four short marginal spines, unarmed ventrally, dorsomedial margin expanded forward; second segment slightly longer than third segment with two or three marginal spines. Stylocerite pointed anteriorly, reaching nearly to outer distal 


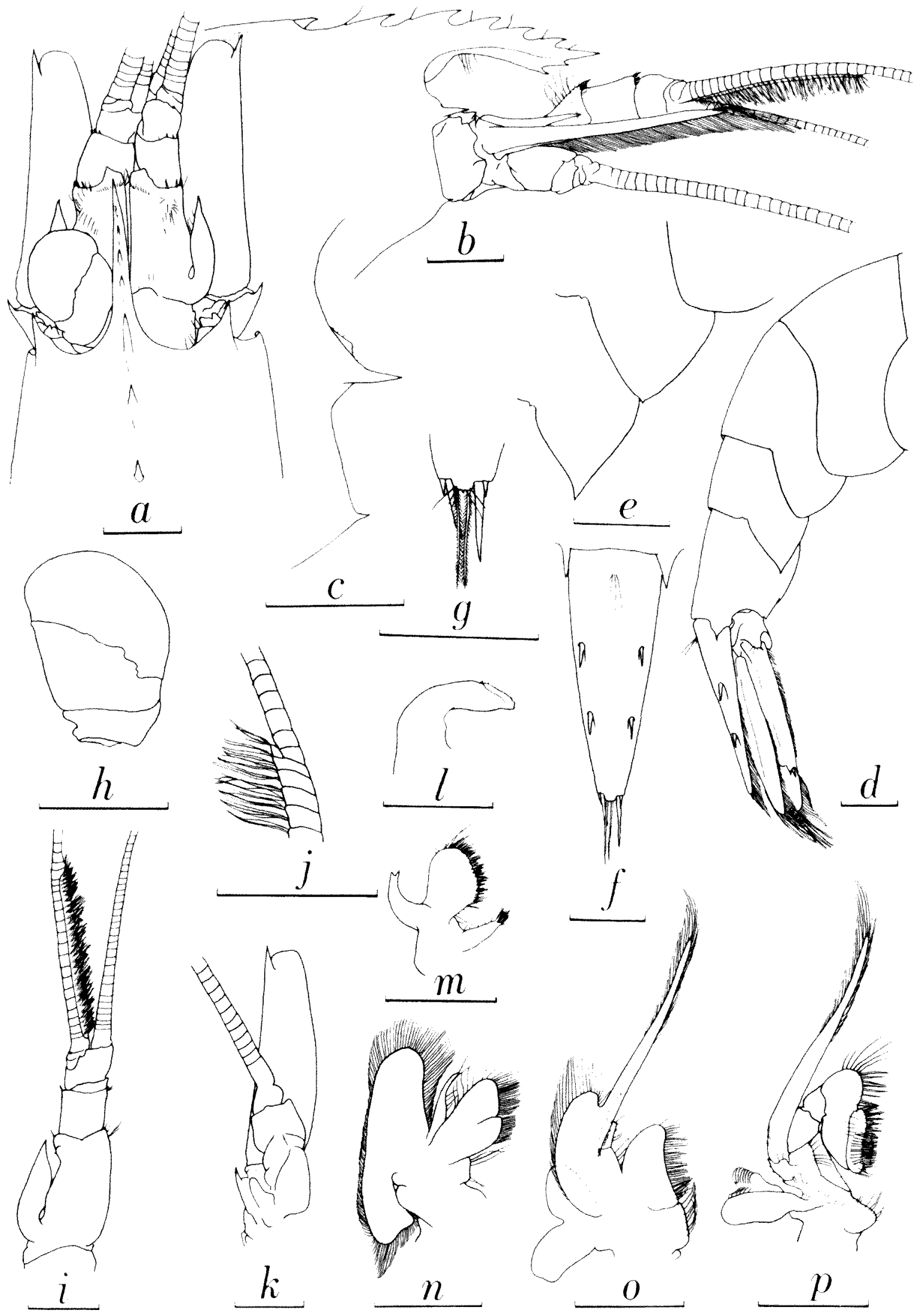

Figure 2 Lysmata disparsp. now. a-d, f-p, holotype (ovig. female, Cl $4.9 \mathrm{~mm}$ ); e, paratype (ovig, female, CL $5.4 \mathrm{~mm}$ ). a, anterior part of body, right eve removed, dorsal view; b, same, lateral view; $c$, anterior margin of carapace, oblique view; d, abdomen, lateral view; e, pleura of third to tifth abdominal somites, lateral view; $f$, telson, dorsal view; $\mathbf{g}$, distal end of telson, dorsal view; $\mathbf{h}$, right eve, dorsal view; $\mathbf{i}$, right antennule, ventral view; $j$, accessory branch of right outer antennular flagellum, mesial view; $k$, right antenna, ventral view; l, left mandible; $\mathbf{m}$, left maxillule; $\mathbf{n}$, left maxilla; $\mathbf{o}$, left first maxilliped; $\mathbf{p}$, left second maxilliped. Scales $1.0 \mathrm{~mm}$. 
margin of first antennular segment (Figure 2i). Outer flagellum longer than body, slightly thickened basal 18-20 joints bearing tufts of dense setae; accessory flagellum very short, consists of only one joint (Figure 2j); inner flagellum as long as outer flagellum, slightly slender. Second antenna with stout scale, extending beyond distal end of antennular peduncle, 3.2-3.3 times as long as wide; outer margin nearly straight or slightly concave, ending in large spine; blade shorter than outer distal spine (Figure 2a, k). Basicerite short, with blunt spine on outer distal margin; carpocerite short, nearly as long as distal margin of first antennular peduncle (Figure $2 b, k$ ); flagellum stout and longer than body.

Mouth parts typical for genus (Figures 2l-p, 3a). Mandible comparatively small, consisting of molar process only, with oblique distal edge (Figure 21). Palp of maxillule feebly bilobed, upper lacinia broad oval, with short setae marginally; lower lacinia slender and short with spinous setae distally (Figure $2 \mathrm{~m}$ ). Palp of maxilla slender, extending as far as level of distal end of distal endite, with two distal setae; scaphognathite well developed, densely setose marginally; distal endite well developed, deeply bilobed, both lobes densely setose medially; proximal endite feebly developed, simple, sparsely with long setae (Figure 2n). First maxilliped with three segmented palp, extending beyond level of distal margin of caridean lobe; exopod well developed, with large caridean lobe; distal and proximal endites simple, densely setose marginally; epipod large, deeply bilobed (Figure 20). Second maxilliped composed of five distinct segments, distal segment narrow, articulated with lower distal part of second segment, armed with some spinous setae and dense marginal setae; second segment with some rather long spinous setae and sparsely long setae; exopod well developed as in first maxilliped; epipod suboval with well lamellate podobranch (Figure $2 \mathrm{p}$ ). Third maxilliped pediform, overreaching distal end of antennular peduncle by distal segment; distal segment tapering densely setose, with three to seven spines distodorsally; penultimate segment short, nearly half as long as distal segment, sparsely setose; proximal segment as long as distal two segments combined, distal two-thirds triangular in cross section, sparsely with line of long setae on each margin; exopod long, reaching distal third of proximal segment; strap like epipod with terminal hook on crescent plate of basal segment (Figure 3a).

First pereopod moderately robust, overreaching antennular peduncle by chela or chela and part of palm (Figure 3b); chela slightly compressed, fingers 0.6 times as long as palm; cutting edges concave proximally making narrow gap when fingers closed; palm smooth, subcylindrical (Figure 3c); carpus cylindrical, 0.9 times as long as chela length; merus 1.3 times as long as carpus, very obliquely articulated with ischium; epipod strap like as in third maxilliped. Second pereopods long and slender, distinctly unequal in length, right leg longer and more robust than left (Figure $3 \mathrm{~d}$, e). Right leg overreaching antennal scale or antennular peduncle by mero-carpal articulation, chela small, cutting edges entire (Figure 3f); carpus slender, long, nine times as long as chela length, composed of 31 or 32 subsegments; merus about half as long as carpus, 21-26 subsegments; ischium slightly shorter than merus, five subsegments (Figure $3 \mathrm{~d}$ ). Left leg overreaching distal margin of first antennular segment by mero-carpal articulation, chela smaller but similar in shape to right one; carpus more than nine times as long as chela, composed of 30 or 31 subsegments, 0.7 times as right leg; merus half as long as carpus, 17-22 subsegments, 0.7 times as long as right leg; ischium as long as merus, five subsegment, 0.8 times as long as right leg (Figure $3 \mathrm{e}$ ).

Third pereopod moderately robust, reaching beyond antennal scale or antennular peduncle by mero-carpal articulation; dactylus compressed, ending in strong claw with four spines on posterior margin (Figure $3 \mathrm{~h}$ ); propodus about four times as long as dactylus, armed with five or six spines on posterior margin; carpus 0.8 times as long as propodus, two very small spines on posterior margin; merus 1.6 times as long as carpus, four or five large spines on distal three-fifths of lateral surface; ischium obliquely articulated with merus, 0.25 times as long as merus, unarmed (Figure $3 \mathrm{~g}$ ).

Fourth pereopod similar in shape to third pereopod, but each segment slightly shorter than that of third pereopod, reaching distal margin of eye by mero-carpal articulation; dactylus same as in third pereopod; propodus with four-six spines on posterior margin; carpus 0.8 times as long as propodus with one or two very small spines on posterior margin; merus 1.5 times as long as carpus, with four or five lateral spines on anterior threefourths (Figure $3 i$ ). Fifth pereopod similar in shape to two preceding pereopods, reaching anterior margin of carapace by mero-carpal articulation; propodus longer than those of two preceding pereopods, with three or four tufts of setae distoposteriorly and one or two spines on posterior margin; carpus as long as that of third pereopod, unarmed; merus distinctly shorter than that of fourth pereopod, with two-four lateral spines (Figure 3j).

First pleopod with endopod tapered, 0.7 times as long as exopod, distally naked, other parts densely setose in ovigerous females; in males endopod tapered, but slightly expanded distally with some coupling hooks (Figure $3 \mathrm{k}$ ). Second to fifth pleopods equally biramous, endopod with appendix interna in both sexes; in males endopod 


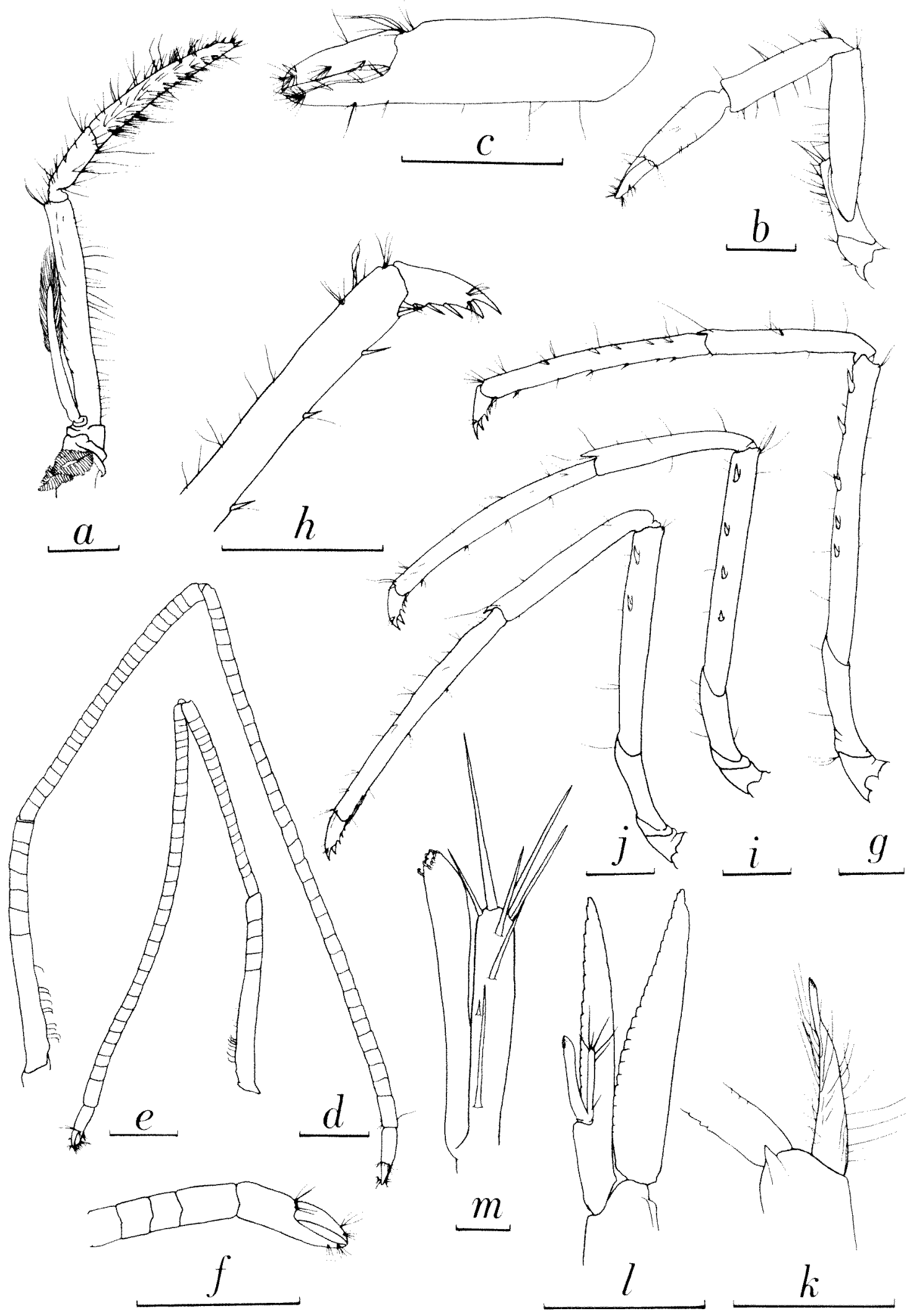

Figure 3 Lysmata disparsp. nov: a, holotype (ovig. female, CL $4.9 \mathrm{~mm}$ ); $\mathbf{b}-\mathbf{j}$, paratype (ovig. female, CL $5.5 \mathrm{~mm}$ ); $\mathbf{k}$ $\mathrm{m}$, paratype male (CL $4.6 \mathrm{~mm}$ ). a, left third maxilliped, lateral view; $\mathrm{b}$, left first pereopod, lateral view; $\mathrm{c}$, chela of right first pereopod, ventral view; d, right second pereopod, lateral view; e, left second pereopod, lateral view; $\mathbf{f}$, chela of left second pereopod, ventral view; $g$, left third pereopod, lateral view; $\mathbf{h}$, dactylus and distal part of propodus of left third pereopod, lateral view; $i$, left fourth pereopod, lateral view; jeft fifth pereopod, lateral view; $k$, endopod of right first pleopod, posterior view; 1 , right second pleopod, setas omitted, anterior view; $\mathbf{m}$, same, appendices masculina and interna. Scales $\mathbf{a}-1,1.0 \mathrm{~mm}, \mathrm{~m}, 0.1 \mathrm{~mm}$. 
of second pleopod with slender appendix masculina, with six long simple setae distally, one short seta mid length, one long simple seta proximally; appendix interna longer than corpus of appendix masculina (Figure $31, \mathrm{~m}$ ).

Uropod longer than telson, outer margin of exopod straight, setose, ending in two small fixed spines with one rather long movable spine between them; diaeresis well marked.

Eggs numerous and small, $0.45 \times 0.70 \mathrm{~mm}$.

\section{Distribution}

Known from the type locality, Goodwyn Island, and Enderby Island, Dampier Archipelago, intertidal to depths of 13-15 m.

\section{Color in life \\ Not reported.}

\section{Etymology}

The specific epithet, Latin dispar means unequal, in reference to the characteristic unequal second pair of pereopods.

\section{Remarks}

The genus Lysmata Risso, 1816 is divided into two species groups on the basis of the outer antennular flagellum having a distinct accessory branch in one group, or accessory branch absent or with no more than two free joints in the other group (Chace, 1997; Wicksten, 2000b), though Holthuis (1947; 1993) recognized them as two separate genera. The new species belongs to the latter group, which was referred to the genus Hippolysmata Stimpson, 1860 by Holthuis (1947; 1993). Chace (1997) included 17 species in this group, although he did not recognize the genus and Wicksten $(2000 \mathrm{~b})$ added two new species in this group.

The present new species is closely related to $L$. olavoi Fransen, 1991, known from the Azores, in having an unequal second pair of pereopods with a carpus of more than 30 subsegments, and a rather long stylocerite reaching nearly to the distolateral margin of the first antennular peduncle. Some species of the genus are considered to have the second pair of pereopods not strictly equal, but subequal. For instance, in a redescription of a specimen from the type locality, Hong Kong, of $L$. vittata, Bruce (1990) showed the right leg slightly longer than the left, and the carpal segmentation a little more numerous in the right leg. In L. olavoi, the right leg is considerably longer than the left leg. The carpus, merus and ischium of the right leg, however, have only one-four more subsegments than the respective segment of the left leg (Fransen, 1991). In the present new species the right leg is longer and larger than the left leg without exception and each segment of the right leg is 1.2-1.4 times longer than the respective segment of the left leg. The numbers of carpal and ischial subsegments of the right side are not evidently different from those of the left side, but the meral subsegments differs considerably; the right leg has four-seven more subsegments than the left. The unequal length and size of the second pereopods are more prominent in the present new species than in L. olavoi.

The rostral teeth and the spine arrangement of the meri of the third and fourth pereopods differ in the two species. There are three rostral teeth on the carapace in $L$. olavoi, while only two in the new species. The meral spines of the third and fourth pereopods are double rows, one on the lateral surface and the other on the posterior margin in $L$. olavoi, and only one row on lateral surface in the new species. Lysmata. olavoi is not a littoral species but a representative of rather deep waters of the eastern Atlantic Ocean.

Lysmata morelandi (Yaldwyn, 1971), known from New Zealand waters, has more than 30 subsegments of the carpus of the second pereopods and a relatively long stylocerite. It, however, differs from the present new species in the absence of the pterygostomial spine and by harbouring double rows of meral spines on the third and fourth pereopods as in L. olavoi

Lysmata amboinensis (De Man, 1888), L. ternatensis De Man, 1902 and L. vittata (Stimpson, 1860) have previously been recorded from Australia (Davie, 2002). During the present survey, $L$. multiscissa (Nobili, 1904) was newly collected from the Dampier Archipelago, as mentioned below. The present new species, therefore, is the fifth species of Lysmata known from Australian waters. It is readily distinguished from the other species by the following characters: $L$. ternatensis bears a long accessory branch on the upper antennular flagellum, and the other three species have a short stylocerite, reaching at most the mid length of the first antennular segment, and they have few articles on the accessory branch of upper antennular flagellum or this is absent. Lysmata amboinensis and $L$. vittata, moreover, have less than 25 subsegments of the carpus of second pereopods.

Other hippolytids collected from the Dampier Archipelago during the survey are as listed below. The species with an asterisk are new to the Australian fauna and briefly introduced.

\section{Gelastocaris paronae (Nobili, 1905)}

\section{Type locality}

Zanzibar (Nobili, 1905).

\section{Material examined}

WAM C 28062 (1 male, 2.9 mm), stn DA3/99/41, S of Norbill Bay, NE of Georgeff Reefs (20 29.24'S, 
116 36.97'E), dive, 1-4 m, 28/29.08.1999; WAM C 28063 (1 female, $2.4 \mathrm{~mm}$ ), stn DA3/99/41, $\mathrm{S}$ of Norbill Bay, NE of Georgeff Reefs $\left(20^{\circ} 29.24^{\prime}\right.$ ', $\left.116^{\circ} 36.97^{\prime} \mathrm{E}\right)$, dive, $1-4 \mathrm{~m}, 28 / 29.08 .1999$; WAM C 28090 (2 males, 2.2, $2.6 \mathrm{~mm}$; 1 ovig. female, $4.4 \mathrm{~mm}$ ), stn DA3/99/65, Enderby I. (20³7.10'S, $\left.116^{\circ} 26.72^{\prime} \mathrm{E}\right)$, dive, $13-15 \mathrm{~m}, 06.09 .1999$.

\section{Distribution}

Wide ranging through the Indo-West Pacific region, from Mozambique to New Caledonia (Chace, 1997). In Australia, Cape Jaubert, N.W. Australia (Balss, 1921), Flat-Top Bank, Timor Sea (Bruce, 1994).

\section{Latreutes mucronatus (Stimpson, 1860)}

\section{Type locality}

Hong Kong (Stimpson, 1860).

\section{Material examined}

WAM C 26530 (1 male, $2.0 \mathrm{~mm}$ ), stn DA3/99/51, Enderby I. $\left(20^{\circ} 35.20^{\prime} \mathrm{S}, 116^{\circ} 30.91^{\prime} \mathrm{E}\right)$, shore, intertidal, 01.09.1999; WAM C 28059 (1 female, 1.8 $\mathrm{mm})$, stn DA3/99/68, Nelson Rocks $\left(20^{\circ} 27.98^{\prime} \mathrm{S}\right.$, $\left.116^{\circ} 39.73^{\prime} \mathrm{E}\right)$, dive, $6.5 \mathrm{~m}, 07.09 .1999$.

\section{Distribution}

Wide ranging through the Indo-West Pacific region, from the Red Sea and South Africa to Indonesia (Chace, 1997). In Australia, Cape Jaubert, N.W. Australia (Balss, 1921), Flat-Top Bank, Timor Sea (Bruce, 1994). Gurney (1937) referred a fourth zoea collected from Great Barrier Reef to this species with some hesitation.

\section{${ }^{*}$ Lysmata multiscissa (Nobili, 1904)}

\section{Type locality}

Djibouti, Red Sea (Nobili, 1904).

\section{Material examined}

WAM C 29208 (1 male, 4.8 mm), stn DA2/99/82, Kendrew I. $\left(20^{\circ} 27.57^{\prime} \mathrm{S}, 116^{\circ} 32.35^{\prime} \mathrm{E}-20^{\circ} 27.18^{\prime} \mathrm{S}\right.$, $\left.116^{\circ} 32.29^{\prime} \mathrm{E}\right)$, rake box dredge, $32-36 \mathrm{~m}, 25.07 .1999$.

\section{Remarks}

The present specimen is a young male, and somewhat resembles the new species $L$. dispar in having only one joint of the accessory branch of the outer antennular flagellum, and the carpus of the second pereopod with 31 subsegments (the left leg is missing). It has a long rostrum, extending beyond the distal end of the antennular peduncle. The dorsal margin is provided with 8 teeth and the ventral margin with 5 teeth. The stylocerite is short, not reaching the midlength of the first antennular segment. These characters distinguish L. multiscissa from L. dispar.

\section{Distribution}

Red Sea (Nobili, 1904; Balss, 1915) and New Caledonia (Monod, 1969), at a depth of $35 \mathrm{~m}$. Lysmata multiscissa is a new member of the Australian fauna.

\section{Lysmata vittata (Stimpson, 1860)}

\section{Type locality}

Hong Kong (Stimpson, 1860).

\section{Material examined}

WAM C 25692 (1 ovig. female, $6.0 \mathrm{~mm}$ ), stn DA1/ 98/31, Searipple Passage $\left(20^{\circ} 31.23^{\prime} \mathrm{S}, 116^{\circ} 51.18^{\prime} \mathrm{E}\right)$, shore, intertidal, 28.10.1998.

\section{Distribution}

Widely ranging throughout the Indo-West Pacific region, from Eastern Africa to Philippines and Indonesia at a depth of $54 \mathrm{~m}$ (Chace, 1997). In Australia, Dirk Hartog Island, W. Australia (Hale, 1929), Low Isles, Great Barrier Reef (McNeill, 1968), Moreton Bay, Queensland (Wadley, 1978), Bullocky Point, Darwin, Northern Territory (Bruce, 1983).

\section{${ }^{*}$ Lysmatella prima Borradaile, 1915} Figure $4 \mathrm{a}-\mathrm{c}$

\section{Type locality}

Maldives (Borradaile, 1915).

\section{Material examined}

WAM C 29207 (1 male, 2.8 mm), stn DA2/99/85, Brigadier I. $\left(20^{\circ} 26.38^{\prime} \mathrm{S}, 116^{\circ} 39.76^{\prime} \mathrm{E}-20^{\circ} 26.09^{\circ} \mathrm{S}\right.$, $116^{\circ} 40.10^{\prime} \mathrm{E}$ ), rake box dredge, 28-29 m, 26 07.1999; WAM C 29206 (1 female, $2.2 \mathrm{~mm}$ ), stn DA2/99/13, Haüy I. $\left(20^{\circ} 26.52^{\prime} \mathrm{S}, 117^{\circ} 00.50^{\prime} \mathrm{E}-20^{\circ} 26.27^{\prime} \mathrm{S}\right)$, $117^{\circ} 00.56^{\prime} \mathrm{E}$, rake box dredge, $19.5 \mathrm{~m}, 16.07 .1999$; WAM C 27549 (1 male, $4.1 \mathrm{~mm}$ ), stn DA3/99/56, Eaglehawk I. $\left(20^{\circ} 38.94^{\prime} \mathrm{S}, 116^{\circ} 26.22^{\prime} \mathrm{E}\right), 2-11 \mathrm{~m}$, 03.09.1999.

\section{Remarks}

The genus Lysmatella Borradaile, 1915 is very similar to the genus Lysmata in general body form. The pereiopods, however, are entirely devoid of an epipod in Lysmatella, but the first four pereopods are provided with the epipod in Lysmata. Lysmatella prima is the only known species of the genus. Three specimens examined are all young, and some characters differ from those of the adults as partly pointed out by Holthuis (1947). The rostrum over-reaches the annennular peduncle and also the antennal scale, and are armed with 8-11 


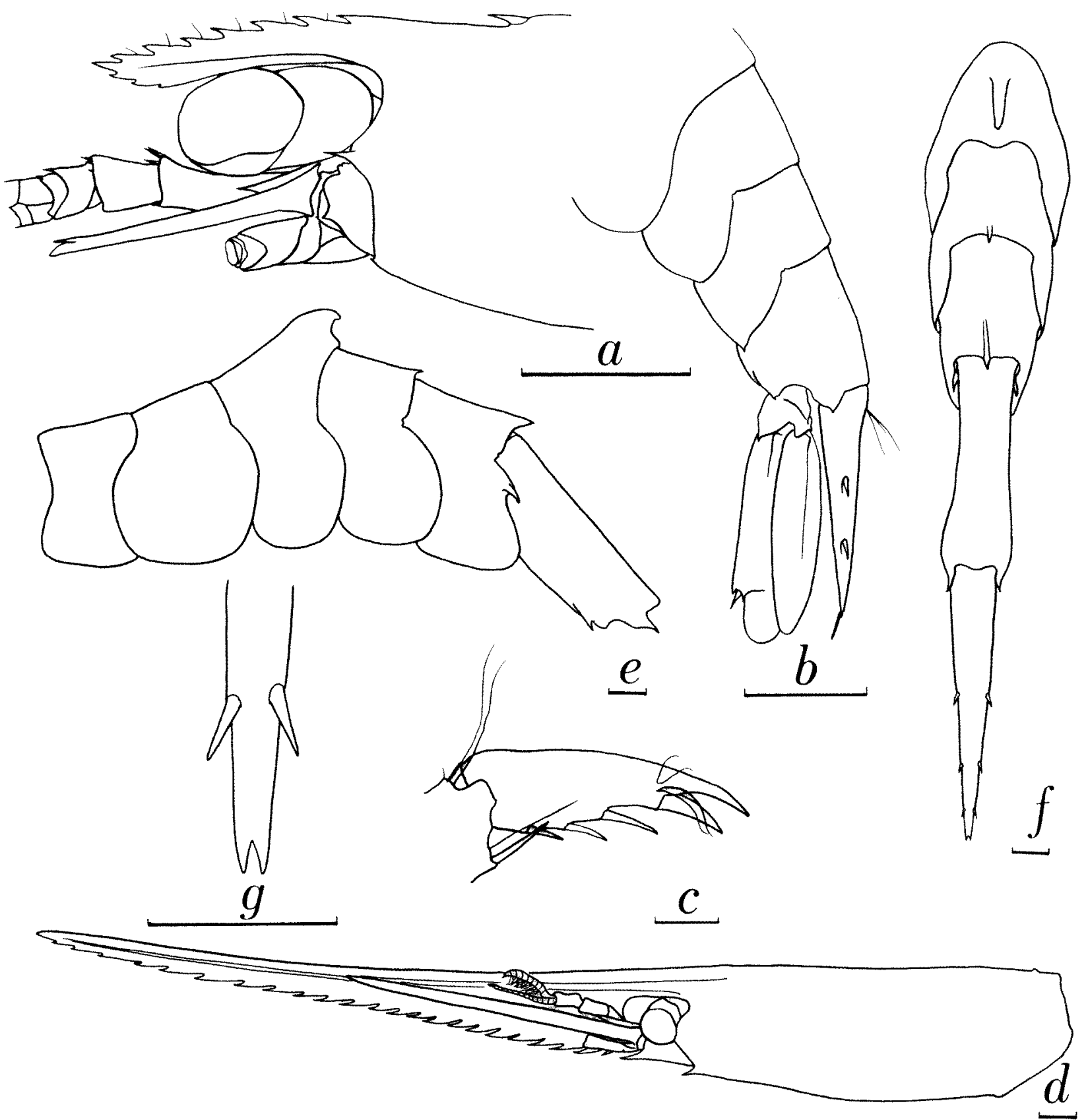

Figure 4 Lysmatella prima Borradaile, 1915: a, c, (female, CL $2.2 \mathrm{~mm}$ ); b, male (CL $2.8 \mathrm{~mm}$ ). Tozeuma armatum Poulson, 1875: d-g, (ovig. female, CL $9.9 \mathrm{~mm}$ ). a, d, anterior part of body, setae omitted, lateral view; b, posterior part of abdomen, setae omitted, lateral view; $\mathbf{c}$, dactylus of third right pereopod, lateral view; $\mathbf{e}$, abdomen, setae omitted, lateral view; $\mathbf{f}$, third to sixth abdominal somites and telson, dorsal view; $\mathbf{g}$, distal end of telson, dorsal view. Scales $\mathbf{a}, \mathbf{b}, \mathrm{d}-\mathrm{g}, 1.0 \mathrm{~mm}, \mathrm{c}, 0.1 \mathrm{~mm}$.

teeth on the dorsal margin and 5-9 teeth on the ventral margin in adults (Borradaile, 1915; Kemp, 1916; Holthuis, 1947; Zarenkov, 1971; Hayashi, 1994a; Chace, 1997). In the present material, however, the rostrum is short, not reaching the distal end of the second antennular peduncle and armed with 6-8 teeth on the dorsal margin and only two teeth on the ventral margin (Figure $4 a$ ). The pleura of the fourth and fifth abdominal somites are sharply pointed in adults (Borradaile, 1917;
Hayashi, 1994a; Chace, 1997), but the spine on the fourth pleuron is weak or entirely absent in the present material (Figure 4b). The dactylus of the third pereopod changes shape with growth. In adults the distal claw is extremely slender, much narrower than the second spine on the posterior margin (Chace, 1997), but in the present material the size of the distal claw is as large as or not extremely more slender than the second spine (Figure 4c). 


\section{Distribution}

Maldive and Andaman Islands, Japan, Philippines, and Indonesia, to a depth of $62 \mathrm{~m}$ (Chace, 1997). New to Australian waters.

\section{Saron marmoratus (Olivier, 1811)}

\section{Type locality}

Australia (Olivier, 1811).

\section{Material examined}

WAM C 28066, (2 males, 4.8, $3.6 \mathrm{~mm}$ ), stn DA3/ 99/42, Georgeff Reef $\left(20^{\circ} 29.34^{\prime} \mathrm{S}, 116^{\circ} 36.80^{\prime} \mathrm{E}\right)$, shore, intertidal, 28.08.1999.

\section{Distribution}

This species is one of the most common hippolytids living associated with coral reefs throughout most of the Indo-West Pacific region (Holthuis, 1947; Chace, 1997). A full synonymy and Australian records of the old literature were listed by Holthuis (1947). Subsequently, the species was reported from the following localities; Low Isles, Great Barrier Reef (McNeill, 1968), Dudley Point, Darwin, Northern Territory (Bruce, 1983).

\section{Thor paschalis (Heller, 1862)}

\section{Type locality}

Red Sea (Heller, 1862).

\section{Material examined}

WAM C 25878 (1 ovig. female, $2.0 \mathrm{~mm}$ ), stn DA1/ 98/10, Angel I. (20 28.41'S, $\left.116^{\circ} 48.48^{\prime} \mathrm{E}\right)$, shore, 0-2 $\mathrm{m}, 20.10 .1998$; WAM C 28051 (1 ovig. female, 2.0 $\mathrm{mm})$, stn DA3/99/36, Malus I. (20³0.06'S, $\left.116^{\circ} 40.58^{\prime} \mathrm{E}\right), 6-14 \mathrm{~m}, 27.08 .1999$; WAM C 28053 (1 ovig. female, $1.9 \mathrm{~mm}$ ), stn DA3/99/37, Malus I. $\left(20^{\circ} 30.61^{\prime} \mathrm{S}, 116^{\circ} 40.92^{\prime} \mathrm{E}\right), 2.0-3.5 \mathrm{~m}, 27.08 .1999$ WAM C 28071 (1 male, $1.5 \mathrm{~mm} ; 2$ ovig. females, 1.9, $2.0 \mathrm{~mm}$ ), stn DA3/99/48, Goodwyn I., (20³2.000'S $\left.116^{\circ} 32.420^{\prime} \mathrm{E}\right)$, intertidal, 31.08.1999; WAM C 28075 (1 male, $1.3 \mathrm{~mm} ; 1$ ovig. female, $2.2 \mathrm{~mm} ; 1$ female, $2.0 \mathrm{~mm} ; 2$ juvs $1.0,0.8 \mathrm{~mm}$ ), stn DA3/99/51, Enderby I. $\left(20^{\circ} 35.20^{\prime} \mathrm{S}, 116^{\circ} 30.91^{\prime} \mathrm{E}\right)$, shore, intertidal, 01.09.1999; WAM C 28088 (1 ovig. female, $2.0 \mathrm{~mm}$ ), stn DA3/99/64, West Lewis I. $\left(20^{\circ} 36.66^{\prime \prime} \mathrm{S}, 116^{\circ}\right.$ 36.94"E), 2.0-5.0 m, rock, 06.09.99; WAM C 25880 (1 male, $1.1 \mathrm{~mm} ; 2$ ovig. females, $2.1,1.7 \mathrm{~mm} ; 2$ juvs, $1.2,1.3 \mathrm{~mm})$, stn DA3/99/68, Nelson Rocks, $\left(20^{\circ} 27.98^{\prime} \mathrm{S}, 116^{\circ} 39.73^{\prime} \mathrm{E}\right)$, dive, $6.5 \mathrm{~m}, 7.09 .1999$.

\section{Distribution}

Thor paschalis is a small species, living throughout the Indo-West Pacific region (Holthuis, 1947), though with some confusion about the synonymy (Chace, 1997). In Australia: Low Isles,
Great Barrier Reef (McNeill, 1968), Dudley Point, Darwin, Northern Territory (Bruce, 1983), Lord Howe Island (Bruce, 1985).

\section{* Tozeuma armatum Paulson, 1875 \\ Figure $4 \mathrm{~d}-\mathrm{g}$}

\author{
Type locality \\ Red Sea (Paulson, 1875).
}

\section{Material examined}

WAM C 29223 (1 ovig. female, $9.9 \mathrm{~mm}$ ), stn DA3/ 99/68, Nelson Rocks (20 27.98'S, 116 39.73'E), dive, associated with gorgonian, $6.5 \mathrm{~m}, 7.09 .1999$.

\section{Remarks}

The present species is characterized by the smooth, hirsute integument, no supraocular tooth, 10-30 teeth on the ventral margin of the rostrum and a single large curved tooth on the third to fifth abdominal somites (Chace, 1997). The present specimen is a full-grown, nearly complete female. The rostrum is 1.7 times as long as the carapace, and armed with 24 teeth along the entire ventral margin (Figure $4 \mathrm{~d}$ ). The dorsal carina of the third abdominal somite is posteriorly high, terminating in a single curved tooth. The fourth and fifth somites are also carinate, each ending in a small tooth, the tooth on the fourth somite is smaller (Figure $4 \mathrm{e}, \mathrm{f}$ ). The pleuron of the fifth abdominal somite is armed with an acute ventrally curved tooth near the upper distal corner. As indicated by Chace (1997), the distal end of the telson is cleft (Figure $4 \mathrm{~g}$ ). Eggs are numerous and small, $0.45 \mathrm{x}$ $0.63 \mathrm{~mm}$. The present specimen agrees with Chace's (1997) diagnosis of $T$. armatum in these characters. There, however, are some discrepancies between them. The dorsal carina of the third abdominal somite is not sharply carinate (Chace, 1997), but flattened dorsally (Figure 4f) like the Japanese female treated by Hayashi (1994b) (NFU 530-2-1692, $C L 10.0 \mathrm{~mm}$ ). The pleuron of the fifth abdominal somite is rounded posteriorly on both sides (Figure $4 \mathrm{e}$ ) in the Australian specimen. These differences seem to be individual variations, because the dorsal margin of the third somite has not seen discussed in detail, except for Chace (1997), and the pleuron of the fifth somite is sometimes rounded posteriorly (Barnard, 1950).

\section{Distribution}

Tozeuma armatum is known from several localities of the Indo-West Pacific region (Holthuis, 1947; Hayashi, 1994b; Chace, 1997), but has not been previously reported from Australia. According to the collecting label, this specimen was associated with a simple, whip-like gorgonian, and the host is included in the storage bottle logether with the 
shrimp. Usually, T. armatum has been collected in a free living condition from surface waters (Holthuis, 1947) or at considerable depths (e.g., 50-110 m: Balss, 1914; Toriyama et al., 1990), but recently commensalisms with whip-like gorgonians has been confirmed (Gosliner et al., 1996; Debelius, 1999; Minemizu, 2000). A similar association is observed in $T$. carolinense Kingsley, 1878, in the western Atlantic and Caribbean, though it is usually found among sea grasses (Voss, 1956).

\section{ACKNOWLEDGEMENTS}

I would like to thank Diana Jones and other staff of the Western Australian Museum for giving me the opportunity to examine the material from the Dampier Archipelago survey. The manuscript was greatly improved by the comments and correction of Dr. Sammy De Grave of Oxford University Museum of Natural History and Dr. Mary K. Wicksten of Texas A\&M University.

\section{REFERENCES}

Balss, H. (1914). Ostasiatische Decapoden II. Die Natantia und Reptantia. In Doflein, F. (ed.), Dekapoden (7) 2. Beiträge zur Naturgeschichte Ostasiens. Abhandlungen der Mathematisch-Physikalischen Klasse der Bayerische Akademie der Wissenschaften (2) 10: 1-101.

Balss, H. (1915). Die Decapoden des Roten Meeres. I. Die Macruren. Expeditionen S.M. Schiff "Pola" in das Rote Meer, Nördliche und südliche Hälfte 1895/961897/98. Zoologische Ergebnisse 30. Berichte der Kommission für Ozeanographische Forschungen. Denkschriften der Akademie der Wissenschaften in Wien 91: 1-38.

Balss, H. (1921). Stomatopoda, Macrura, Paguridea und Galatheidea. In, Results of Dr. E. Mjöberg's Swedish Scientific Expeditions to Australia 1910-13, XXIX. Kungliga Svenska Vetenskapsakademiens Handlingar 61 (10): 1-24.

Barnard, K.H. (1950). Descriptive catalogue of South African Decapod Crustacea (Crabs and Shrimps). Annals of the South African Museum 38: 1-837.

Borradaile, L.A. (1915). Notes on carides. Annals and Magazine of Natural History 15: 205-213.

Borradaile, L.A. (1917). On Caridea from the Western Indian Ocean. In, The Percy Sladen Trust Expedition to the Indian Ocean in 1905, under the leadership of Mr. J. Stanley Gardiner M.A. 7 (9). Transactions of the Linnnean Society of London 17: 397-412.

Bruce, A.J. (1983). Additions to the marine fauna of the Northern Territory. I. Decapod Crustacea: Caridea and Stenopodidae. The Beagle 1: 41-49.

Bruce, A.J. (1985). Caridean shrimps from Lord Howe Island. The Beagle 1: 123-130.

Bruce, A.J. (1990). Redescriptions of five Hong Kong carideans first described by William Stimpson, 1860. In Morton, B. (ed.), The Marine Flora and Fauna of Hong Kong and Southern China 2: 569-610.
Bruce, A.J. (1994). Shrimps from Flat-Top Bank, Timor Sea (Crustacea: Decapoda: Caridea). Raffles Bulletin of Zoology 42: 743-756.

Burukovsky, R.N. (2000). Lysmata splendida sp. nov., a new species of shrimp from the Maldives (Crustacea: Decapoda: Hippolytidae). Senckenbergiana maritima 30: $223-227$.

Chace, F.A., Jr. (1997). The caridean shrimps (Crustacea:Decapoda) of the Albatross Philippine Expedition, 1907-1910, Part 7: Families Atyidae, Eugonatonotidae, Rhynchocinetidae, Bathyalemonellidae, Processidae, and Hippolytidae. Smithsonian Contributions to Zoology 587: 1-106.

Davie, P.J.F. (ed.) (2002). Crustacea: Malacostraca: Phyllocarida, Hoplocarida, Eucarida (Part 1), Zoological Catalogue of Australia 19.3A. Melbourne, Australia, CSIRO Publishing, xii+551 pp.

Debelius, H. (1999). Crustacean Guide of the World. IKAN-Unterwasserarchiv, Frankfurt, 321 pp.

Fransen, C.H.J.M. (1991). Lysmata olavoi, a new shrimp of the family Hippolytidae (Decapoda, Caridea) from the eastern Atlantic Ocean. Life and Earth Sciences 9: 63-73.

Gosliner, T.M., Behrens, D.W. and Williams, G.C. (1996). Coral reef animals of the Indo-Pacific. Sea Challengers, Monterey, California, 314 pp.

Gurney, R. (1937). Larvae of Decapod Crustacea. Part IV. Hippolytidae. Discovery Reports 14: 351-404.

Hale, H.M. (1929). Crustacea. Notes on the Fauna of Dirk Hartog Island, Western Australia. No. 4. Transactions and Proceedings of the Royal Society of South Australia 53: 67-70.

Hayashi, K. (1994a). Prawns, shrimps, and lobsters from Japan (78). Family Hippolytidae. Genera Lysmatella and Lysmata. Aquabiology 93: 270-274 (in Japanese).

Hayashi, K. (1994b). Prawns, shrimps, and lobsters from Japan (79). Family Hippolytidae. Genus Tozeuma and key to genera of Hippolytidae. Aquabiology 94: 355358 (in Japanese).

Heller, C. (1862) Beiträge zur Crustaceen-Fauna des rothen Meeres. Zweiter Theil. Sitzungsberichte der Akademie der Wissenschaften in Wien 44: 241-295.

Holthuis, L.B. (1947). The Hippolytidae and Rhynchocinetidae collected by the Siboga and Snellius Expeditions with remarks on other species. The Decapoda of the Siboga Expedition, Part IX, Siboga Expeditie (39a) 25: 1-100.

Holthuis, L.B. (1993). The recent genera of the caridean and stenopodidean shrimps (Crustacea, Decapoda), with an appendix on the order Amphionidacea. Nationaal Natuurhistorisch Museum, Leiden, $328 \mathrm{pp}$.

Kemp, S. (1916). Notes on Crustacea Decapoda in the Indian Museum. VII. Further notes on Hippolytidae. Records of the Indian Museum 12: 385-405.

Kingsley, J.S. (1978). Notes on the North American Caridea in the Museum of the Peabody Academy of Science at Salem, Mass. Proceedings of the Academy of Natural Sciences of Philadelphia 1878: 89-98.

Man, J.G. de (1888). Bericht über die von Herrn Dr. J. Brock im indischen Archipel gesammelten Decapoden und Stomatopoden. Archiv für Naturgeschichte 53: 215-600. 
Man, J.G. de (1902). Die von Herm Professor Kükenthal im Indischen Archipel gesammelten Dekapoden und Stomatopoden. In Kükenthal, W. Ergebnisse einer zoologischen Forschungsreise in den Molukken und Borneo. Abhandlungen der Senckenbergischen Naturforschenden Gesellschaft 25: 467-929.

Minemizu, R. (2000) Marine decapod and stomatopod crustaceans mainly from Japan. Bunichisougoushuppan Co. Ltd. 344 pp. (in Japanese)

McNeill, F.A. (1968). Crustacea, Decapoda and Stomatopoda. Scientific Reports of Great Barrier Reef Expedition 1928-297: 1-98.

Monod, Th. (1969). Sur quatre crevettes de Nouméa (Nouvelle-Caledonie). Cahiers du Pacifique 13: 15222.

Nobili, G. (1904). Diagnoses préliminaires de vingt-huit especes nouvelles de Stomatopodes et Décapodes Macroures de la Mer Rouge. Bulletin du Muséum d'Histoire Naturelle 10: 228-238.

Nobili, G. (1905). Crustacei di Zanzibar. Bollettino dei Musei di Zoologia ed Anatomia Comparata della $R$. Universita di Torino 20: 1-12.

Olivier, A.G. (1811). Palémon: Palaemon. pp 652-667. In Diderot and d'Alembert (premiers), (eds), Encyclopédie Méthodique d'Histoire naturelle des Insectes, Paris: H. Agasse. Vol. 8: 722 pp

Paulson, O. 1961 (1875). Studies on Crustacea of the Red Sea with notes regarding other seas. Part 1. Podophthalmata and Edriophthalmata (Cumacea). Israel Program for Scientific Translations L.td., Jerusalem. $143 \mathrm{pp}, 21 \mathrm{pls}$.

Risso, A. (1816). Histoire naturelle des Crustacés des environs de Nice. Paris. 175 pp, 3 pls.
Stimpson, W. (1860). Prodromus descriptionis animalium evertebratorum quae in expeditione oceanum Pacificum Septentrionalem a Republica Federata missa, C. Ringgold et J. Rodgers ducibus, observavit et descripsit. Proceedings of the Academy of Natural Science, Philadelphia 12: $22-48$.

Toriyama, M., Horikawa, H. and Kishida, S. (1990). Preliminary reports on ten rare caridean shrimps (Decapoda, Caridea) from Tosa Bay and its adjacent waters. Bulletin of Nansei National Fisheries Research Institute 23: 13-26.

Voss, G.L. (1956). Protective coloration and habitat of the shrimp Tozeuma carolinensis Kingsley, (Caridea: Hippolytidae). Bulletin of Marine Science of the Gult and Caribbean 6: 359-363.

Wadley, V.A. (1978). A checklist and illustrated key to the epibenthic shrimps (Decapoda: Natantia) of Moreton Bay, Queensland. CSIRO Division of Fisheries and Oceanography 99: 1-24.

Wicksten, M.K. (2000a). A new species of Lysmata (Caridea: Hippolytidae) from the eastern Pacific. Crustaceana 73: 207-213.

Wicksten, M.K. (2000b). The species of Lysmata (Caridea: Hippolytidae) from the eastern Pacific Ocean. Amphipacifica 11: 3-22.

Yaldwyn, J.C. (1971) Preliminary descriptions of a new genus and twelve new species of natant decapod Crustacea from New Zeland. Records of the Dominion Museum 7: 85-94.

Zarenkov, N.A. (1971). A contribution to the fauna and geographic distribution of shrimps of the families Pandalidae and Hippolytidae. The Complex Investigation of Ocean Nature, Moscow University 2: 176-195 (in Russian). 